\title{
APPLICATION OF AGROTOXICS IN THE RURAL AREA OF PARA
}

\section{Lucas Ruann Lima Ferraz ${ }^{1}$, David Barbosa de Alencar ${ }^{2}$ and Igor Felipe Oliveira Bezerra ${ }^{3}$}

\author{
${ }^{1}$ Braulo Cardoso de Mattos Higher Education Institute - FASERRA. Manaus-Amazonas, Brazil. \\ ${ }^{2,3}$ Nilton Lins University. Manaus-Amazonas, Brazil.
}

Email: lucasruannferraz@gmail.com, david002870@ hotmail.com, igor.bezerra@uninilton.edu.br

Received: Aug $23^{\text {th }}, 2019$

Accepted: Aug $30^{\text {th }}, 2019$

Published: December 02 ${ }^{\text {th }}, 2019$

Copyright (C2016 by authors and Galileo Institute of Technology and Education of the Amazon (ITEGAM).

This work is licensed under the Creative Commons Attribution International License (CC BY 4.0).

https://creativecommons.org/licen ses/by/4.0/

\section{ABSTRACT}

The pesticide has been used over time to optimize agricultural production and prevent certain types of unwanted fungi or herbs in its production with certain pesticides making it harmful to health both by consuming and especially by creating a direct contact, using as base the work safety standards imposed by federal law. 7,802, July 11, 1989 and Decree 4,074, January 4, 2002, NR15 and NR31 aiming at the correct application of pesticides and better storage using the field research methodology, photographic records and questionnaires with the rural worker, resulting in non-compliance with the same already mentioned for lack of correct use of PPE during the application and lack of MSDS (Chemical Safety Data Sheet) at the storage site, however in view of the information presented, attention is needed with the rural worker and his quality of work.

Keywords: Pesticide; Methodology; Safety.

\section{INTRODUTION}

Pesticides emerged in World War II for the purpose of functioning as a chemical weapon. After the war, the product was used as a pesticide, becoming also known as pesticide, pesticide or phytosanitary product. In Brazilian law, the term used is pesticide, despite attempts to change it.

Since the 1950s, with the so-called "Green Revolution", agricultural production has undergone many changes. The agricultural process has been modernized through seed research, soil fertilization and field machinery. All this to boost productivity. Much of this technology also involved the widespread use of pesticides in order to control pests so as not to have losses in the agricultural process, since pesticides have the function of altering the composition of fauna and flora.

According to [1] Law No. 7802/89, "pesticides are chemicals intended for use in the production, storage and processing of agricultural products, pastures, protection of native or implanted forests, and other ecosystems. and also, of urban, water and industrial environments, whose purpose is to change the composition of fauna or flora, in order to preserve them from the harmful action of living beings considered harmful, as well as substances and products used as defoliants, desiccants, stimulants and inhibitors. of growth ". Growth regulators are also considered agricultural defensives.

\section{B IBLIOGRAPHIC REFERENCE}

According to [2] there are 20,000 deaths / year as a result of pesticide manipulation, inhalation and direct consumption in developing countries such as Brazil. Organophosphate pesticides including tamoron basically cause three types of neurological sequelae after acute intoxication due to chronic exposure: delayed plineuropathy (progressive weakness and ataxia of the legs, which may progress to flaccid paralysis), intermediate syndrome (paralysis that mainly affects the neck flexor muscles, leg and respiratory muscles, and intensive diarrhea) and behavioral effects (insomnia or disturbed sleep, anxiety, delayed reactions, difficulty concentrating, and a variety of psychiatric sequelae: apathy, irritability, schizophrenia, difficulty in thinking, failures memory and depression) [3].

His work [4] states that the regulation provided by Law No. 7,802 / 89 emphasizes the importance of controlling the use of pesticides, since there is an excessive and improper use of these substances mainly motivated by the misinformation of their real dangers.

The correct use of phytosanitary products required the correct use of protective equipment (PPE). The current recommendations for the use of PPE are quite generic and standardized, not considering important variables such as the type of equipment used in the operation, the actual exposure levels and even the environmental and crop characteristics where the product 
will be applied. These variables often result in unnecessary spending, inappropriate recommendations, and may increase workers' risks rather than decrease them [5].

Depending on the type of product used and triangulating a parameter such as exposure time, a type of degree of health, minimum, medium and maximum can be defined, to be cautious before the worker directly influencing their salary [6].

Qualification programs developed by official rural extension agencies and services, middle and higher education institutions in agricultural sciences and the National Rural Learning Service (SENAR), trade unions, rural producers' associations, agricultural production cooperatives or forestry and professional associations, provided that the criteria established by this standard are met, ensuring the free choice of any of these by the employer [7].

The impact of pesticide use on human health has been addressed as one of the top priorities of the entire scientific community around the planet, particularly in developing countries where these chemicals are widely used in agricultural production. Developing countries account for $30 \%$ of the global pesticide consumer market, with Brazil being the largest single consumer market among these countries, equivalent to half of all consumption in the Latin American region [8].

This publication presents contributions from some research groups that have been dealing with the challenges presented here in Brazil and Latin America in the last two decades. It is a sample of the growing scientific output on the health and environmental effects of pesticide use in rural activities and is part of the efforts of the Oswaldo Cruz Foundation and Mount Sinai School of Medicine to bring together professionals from across the Latin region. -American project with a main objective: to narrow the gap between the environmental and health sciences and thus contribute to the promotion of a better quality of life and work for all rural workers in Latin America [9].

The idea of "taking it" that emerges in the analysis shows that individuals are facing a knowledge that imposes a type of behavior and says that there are no alternatives. Acting differently, i.e. adopting new behaviors, such as using PPE and following expertly established standards of protection, could be for this group at odds with the common sense that fatality should be accepted and at odds with the "rule". that it is normal not to protect oneself [10].

Pesticides can be seen as a necessary input to the viability of most rural production systems, since many of these rural production systems would only be sustained due to the use of pesticides to compensate for their lost productivity. In many cases the use of pesticides could be considered as a matter of survival. For most farmers and rural workers, an agricultural crop without pesticides would not be a viable alternative [11].

The use of pesticides seemed in most cases to try to maximize economic efficiency and increase rural productivity, bringing additional socioeconomic benefits. However, assuming the inverse relationship between economic efficiency and socioenvironmental justice as true, it would be necessary for some communities to accept (willingness to accept) a certain amount of additional socio-environmental risk caused by the use of pesticides [11].

\section{MATERIAL AND METHODS}

The field research was carried out with activities developed with the community object of the study, through direct visits to the properties to collect specific information directed to the theme addressed, that is, related to the way in which the farmer acquires and uses pesticides. in the development of rural activities, and how this affects their health, their way of life and the environment.

\section{III.1 RESEARCH PLACE}

The research was developed in the locality called barrier road towards legal Brasilia, near the municipality of Itaituba state of Pará, this region has as one of its main sources of income agriculture and livestock, the pesticides have as aid in the production of this source of income. so present in the region.

\section{TYPE OF RESEARCH}

The work carried out is based [12], according to him the field research modality, uses the method called Descriptive Research where it was prioritized to observe, register, correlate and describe facts and phenomena of a reality of a community without causing changes or manipulations in the middle.

Following the line of reasoning of [12] was made use of the technique of data patterns applied through a questionnaire observing the sitmatic of the present study site.

\section{IV.1 DATA COLLECTION INSTRUMENTS}

The collected data was generated through visits to the locality observing the local worker site before the application of the pesticide, during and after the application and then observing the use of PPE during the entire process and storage sites of Epi and agrotoxic agents, the photos of rescues during application were taken from a distance considered safe by the researcher of this article himself, such action was taken as there was no PPE.

\section{IV.2 RESEARCH FORM}

Table 1: Questionnaire.

\begin{tabular}{|c|c|}
\hline $\begin{array}{l}\text { 1. Do you use pesticides } \\
\text { to control pests and } \\
\text { unwanted herbs? }\end{array}$ & ( ) Yes ( ) No \\
\hline \multirow{4}{*}{$\begin{array}{l}\text { 2. How often do you use } \\
\text { the pesticide }\end{array}$} & ( ) Daily \\
\hline & ( ) Weekly \\
\hline & ( ) Monthly \\
\hline & ( ) Others \\
\hline \multirow{3}{*}{$\begin{array}{l}\text { 3. Where is it from get } \\
\text { from pesticide }\end{array}$} & ( ) Farm Shop \\
\hline & ( ) Online platform \\
\hline & ( ) Unknown "Street Vendors" \\
\hline \multirow{4}{*}{$\begin{array}{l}\text { 4. Do you receive } \\
\text { professional guidance } \\
\text { from the area? }\end{array}$} & ( ) Agronomist Engineer \\
\hline & ( ) Agricultural store clerk \\
\hline & ( ) Neighbors of the region \\
\hline & ( ) Does not receive guidance \\
\hline \multirow{4}{*}{$\begin{array}{l}\text { 5. Can you identify the } \\
\text { toxicological } \\
\text { classification when } \\
\text { purchasing the } \\
\text { pesticides class } 1 \text { - } \\
\text { extremely class 2- } \\
\text { highly toxic class 3- } \\
\text { medium toxic class } 4 \text { - } \\
\text { little toxic }\end{array}$} & ( ) Yes ( ) No \\
\hline & ( ) By band color \\
\hline & $\begin{array}{l}\text { ( ) Reading the label and / or the } \\
\text { package leaflet }\end{array}$ \\
\hline & ( ) Other................. \\
\hline \multirow{3}{*}{$\begin{array}{l}\text { 6. Uses PPE's for } \\
\text { pesticide application }\end{array}$} & ( ) Yes, Full \\
\hline & ( ) Yes, Partial \\
\hline & ( ) Not use \\
\hline
\end{tabular}

Source: Authors, (2019). 


\section{IV.3. STANDARDS APPROVED FOR WORK}

NR 15 - Unhealthy Activities and Operations Annex No. 13 - List of activities and operations involving chemical agents considered unhealthy due to workplace inspection. Excluding basket activities or operations with constant chemical agents, the rural worker who works exposed to contact with chemical agents and pesticides has the right to unhealthy work from 1973, when Law No. 5,589/ 73 came into force., which regulates rural activity.

Following the above NR context, the level of healthiness in the workplace in this proposed article is medium level.

NR 31 - The purpose of this Regulatory Standard is to establish the precepts to be observed in the organization and in the work environment, so as to make the planning and development of the activities of agriculture, livestock, forestry, logging and aquaculture compatible with safety and occupational health and environment.

\begin{tabular}{|c|c|c|c|c|c|}
\hline $\begin{array}{c}\text { Number of } \\
\text { workers }\end{array}$ & $\begin{array}{c}\text { Work } \\
\text { safety } \\
\text { engineer }\end{array}$ & $\begin{array}{c}\text { Occupational } \\
\text { Physician }\end{array}$ & $\begin{array}{c}\text { Occupational } \\
\text { Safety } \\
\text { Technician }\end{array}$ & $\begin{array}{c}\text { Work } \\
\text { nurse }\end{array}$ & $\begin{array}{c}\text { Nursing } \\
\text { assistant }\end{array}$ \\
\hline 51 to 150 & & & 1 & & 1 \\
\hline 151 to 300 & & & 1 & & 1 \\
\hline 301 to 500 & & 1 & 2 & & 1 \\
\hline 501 to 1000 & 1 & 1 & 2 & 1 & 1 \\
\hline Over 1000 & 1 & 1 & 3 & 1 & 2 \\
\hline
\end{tabular}

Figure 1: Table of professionals by number of employees in the company.

Source: [7].In the table above we have the occupational safety professional (s) corresponding to the number of employees in the workplace and around.

\section{RESULTS AND DISCUSSION}

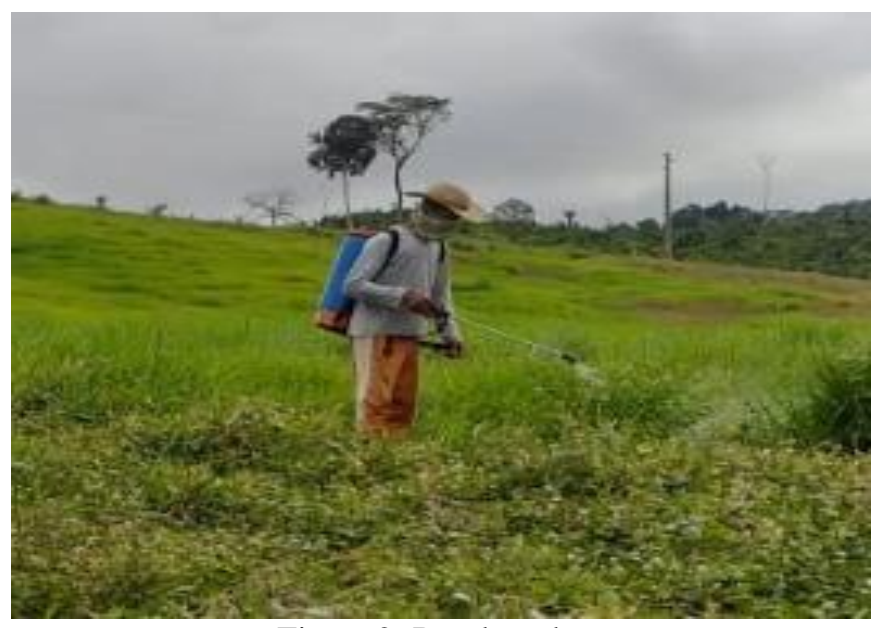

Figure 2: Rural worker.

Source: Authors, (2019).

After surveying the analysis of occupational safety standards NR15, NR31 and decrees such as "DECREE No. 4,074, JANUARY 4, 2002", it was concluded, as illustrated in Figure 2, that the current employee is not in debt. protected for their duties in applying the pesticide pesticide weekly, lacking the use of appropriate PPE's such as gloves, mask, protective hat and clothing that prevent the product from penetrating your skin, all for the sake of safe work aiming to have no worrying symptoms in the future. Your health.

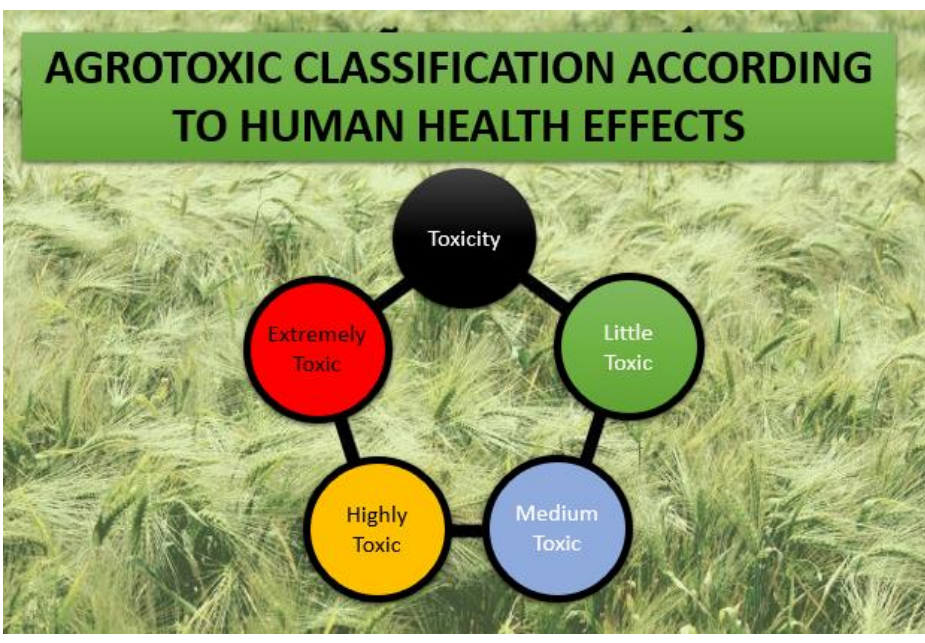

Figure 3: Color toxicity illustration. Source: [13].

Toxicological class, band color on the product label and lethal dose 50 (DL50), thus making it easy for the worker to know the degree of danger of the product being handled.

\begin{tabular}{|c|c|c|c|}
\hline \multicolumn{2}{|c|}{ Toxicological class } & Band Color & Lethal Dose (LD50) \\
\hline Class I & Extremely Toxic & Red & $<5 \mathrm{mg} / \mathrm{kg}$ \\
\hline Class II & Highly toxic & Yellow & $5-50 \mathrm{mg} / \mathrm{kg}$ \\
\hline Class III & Toxic Medium & Blue & $50-500 \mathrm{mg} / \mathrm{kg}$ \\
\hline Class IV & Toxic & Green & \\
\hline
\end{tabular}

Figure 4: Dose in mg of lethality.

Source: [14].

As has already been identified in Figure 4 the degree of hazardousness being identified by color, going deeper here in Figure 5 identifies the lethality dose in $\mathrm{mg} / \mathrm{kg}$ and an illustrative idea as 1 teaspoon for the lethal dose.

Table 2: Table of confirmed cases.

\begin{tabular}{|c|c|}
\hline Epidemiological Indicators & YEAR 2007 TO 2017 \\
\hline \multicolumn{1}{|c|}{ confirmed cases } & 40,000 (forty thousand) \\
\hline death toll & 1,900 (nineteen hundred) \\
\hline $\begin{array}{l}\text { Pesticide consumption in 2017 in } \\
\text { Brazil }\end{array}$ & 500 thousand tons \\
\hline
\end{tabular}

Source: [13].

In Table 2 we see the cases of people affected by the pesticide within 10 years showing all concern with those who have direct contact with these products.

\section{FINAL CONSIIDERATIONS}

The objective of this work was to work on safety standards focused on the use of pesticides from storage to direct application, showing in various views the negative effects of direct contact and their precautions al ways based on safety standards. as NR15 annex 13 and NR 31 showing the need and attention to the rural worker and applying due healthiness to the rural worker salary, in order to reach this conclusion field surveys were conducted based on a questionnaire and photographic records for a test. More concrete need for the application of occupational safety standards, bringing the purpose of this article to comply with the rules keeping the 
work safe and healthy avoiding that the company responsible has no problems with processes or even compensation reducing risks for both parties.

\section{REFERENCES}

[1] De Bessa Antunes, Paulo. Direito ambiental. Editora Lumen Juris, 2008.

[2] Cerqueira, Gilberto Santos, et al. Dados de Exposição Ocupacional aos Agrotóxicos em um Grupo Assistido por uma Unidade Básica de Saúde na Cidade de Cajazeiras, PB. Revista Intertox de Toxicologia, risco ambiental e sociedade, 2015, 3.1.

[3] Pereira, Karla Elita Viegas. Uso de Defensivos Naturais, Uma Alternativa Saudável e Rentável. Revista Brasileira de Agroecologia, 2009, 4.2.

[4] Bohner, Tanny Oliveira Lima; De Araujo, Luiz Ernani Bonesso; Nishijima, Toshio. A biossegurança no uso de defensivos agrícolas na percepção dos agricultores do município de Chapecó, SC. Revista Eletrônica do Curso de Direito da UFSM, 2013, 8: 690-699.

[5] De Oliveira, Alan Martins, et al. Controle biológico de pragas em cultivos comerciais como alternativa ao uso de agrotóxicos. 2006.

[6] Regulamentadora, Norma. NR-15: Atividades e operações insalubres. Brasília: MTE, 2007.

[7] Regulamentadora, Norma. NR-31. Segurança e saúde no trabalho na agricultura, pecuária silvicultura, exploração florestal e aquicultura, do Ministério do Trabalho e emprego. Portaria GM n ${ }^{\circ}$ 86, de 3 de março de 2005.

[8] Bedor, Cheila Nataly Galindo, et al. Vulnerabilidades e situações de riscos relacionados ao uso de agrotóxicos na fruticultura irrigada. Revista Brasileira de Epidemiologia, 2009, 12: 39-49.

[9] Recena, Maria Celina Piazza; Caldas, Eloisa Dutra. Percepção de risco, atitudes e práticas no uso de agrotóxicos entre agricultores de Culturama, MS. Revista de Saúde Pública, 2008, 42: 294-301.

[10] Faria, Neice Müller Xavier, et al. Trabalho rural e intoxicações por agrotóxicos. Cadernos de Saúde Pública, 2004, 20: 1298-1308.

[11] Czeresnia, Dina; De Freitas, Carlos Machado. Promoção da saúde: conceitos, reflexões, tendências. SciELO-Editora FIOCRUZ, 2009.

[12] Rodrigues, William Costa, et al. Metodologia científica. Faetec/IST. Paracambi, 2007.

[13] Brasil. Decreto $\mathrm{n}^{\circ} 4.074$, de 4 de janeiro de 2002. Regulamenta a Lei $\mathrm{n}^{\circ} 7.802$, de 11 de julho de 1989 , que dispõe sobre a pesquisa, a experimentação, a produção, a embalagem e rotulagem, o transporte, o armazenamento, a comercialização, a propaganda comercial, a utilização, a importação, a exportação, o destino final dos resíduos e embalagens, o registro, a classificação, o controle, a inspeção e a fiscalização de agrotóxicos, seus componentes e afins, e dá outras providências. Diário Oficial [da] União, Poder Executivo, 2002.
[14] Organização Pan-Americana Da Saúde. Manual de vigilância da saúde de populações expostas a agrotóxicos. 1996. 